\title{
Article
}

\section{Changing corporate domicile: The case of the rhodesian selection trust companies}

Mollan, Simon, Frank, Billy and Tennent, Kevin

Available at http://clok.uclan.ac.uk/33765/

Mollan, Simon, Frank, Billy ORCID: 0000-0001-6789-078X and Tennent, Kevin (2020) Changing corporate domicile: The case of the rhodesian selection trust companies. Business History . ISSN 0007-6791

It is advisable to refer to the publisher's version if you intend to cite from the work. http://dx.doi.org/10.1080/00076791.2020.1763308

For more information about UCLan's research in this area go to

http://www.uclan.ac.uk/researchgroups/ and search for <name of research Group>.

For information about Research generally at UCLan please go to http://www.uclan.ac.uk/research/

All outputs in CLoK are protected by Intellectual Property Rights law, including Copyright law. Copyright, IPR and Moral Rights for the works on this site are retained by the individual authors and/or other copyright owners. Terms and conditions for use of this material are defined in the policies page. 
Changing corporate domicile: the case of the Rhodesian Selection Trust companies

Simon Mollan ${ }^{a}$, Billy Frank ${ }^{b}$ and Kevin Tennent ${ }^{c}$

\begin{abstract}
This article explores the transfer of corporate domicile of the Rhodesian Selection Trust group of "Free-Standing Companies" (FSCs) from the UK to Northern Rhodesia. To explore the 'nationality of the company' we question how political and economic factors affected strategic decision-making. We contribute further understanding of the impact of international double taxation to the history of FSCs. The article illustrates how the 'nationality of the firm' became a contested zone of interaction as British imperial power waned, American capital investment became more dominant, and colonies began to assert themselves in their own 'national' interests. We conclude that international taxation was a decisive factor in the relocation of domicile, and was linked to changes in the organizational forms adopted by international business in this period. We use this to contribute to the historiographical debate about the decline of FSCs in the international economy, and the position of business in decolonization.
\end{abstract}

\title{
Keywords:
}

International taxation; international business history; Free-Standing Companies; Zambia/Northern Rhodesia; domicile; imperialism; colonialism.

\footnotetext{
a The York Management School, University of York, York, UK

${ }^{\mathrm{b}}$ School of Humanities and Social Sciences, University of Central Lancashire, Preston, UK

c The York Management School, University of York, York, UK
} 


\section{Introduction}

In the period before 1914 Britain was the world's leading foreign direct investor. ${ }^{1}$ The main corporate vehicle for this investment was the "Free-Standing Company"(FSC). ${ }^{2}$ Though FSCs originated in several European countries, the vast majority were "British" with head offices located in London, Dundee or Edinburgh. ${ }^{3}$ FSCs undertook business around the globe in areas as diverse as extractive industries, banking, agriculture, international trade, railways, and public utilities. ${ }^{4}$ FSC research has generally focused on explaining their initial formation and there is little in the literature explaining why this largely British corporate form disappeared in the mid-Twentieth Century. ${ }^{5}$ However, Wilkins (1998) speculated that one factor that explained the disappearance of these firms was the rise of international taxation. ${ }^{6}$ In a recent article Mollan and Tennent (2015) added confirmatory evidence to this hypothesis, arguing that international taxation created a hostile environment for FSCs encouraging both the adoption of multinational multi-unit forms, as well as the re-location of head office domicile, as a means of reducing or eliminating this tax burden. ${ }^{7}$ This article further explores this explanation for the 'disappearance' of FSCs, by examining in detail how and why the Rhodesian Selection Trust (RST) group of mining companies ceased to be identifiably "British" firms by moving their place of residence (domicile) as a result of taxation and colonial politics.

The contested nationality of multinational and international firms is central to the purpose of this special issue. An approach to understanding this is to look at instances of when companies or firms sought to change their national domicile. Between February and July 1952 the RST group applied to change their domicile from the UK to Northern Rhodesia (known as Zambia after independence in 
1964). ${ }^{8}$ The Treasury appointed an advisory panel to consider the application. They reported in November 1952 and approved the change. By July 1953 the RST group had successfully moved domicile to Northern Rhodesia. ${ }^{9}$ This brief outline chronology of events, however, masks divergence and dissonance among the main actors in the process. Within the RST group there was an internal debate about the strategy. The intention to change domicile was initially resisted by the British government for tax revenue and balance of payments reasons. However, the conflict within the British state was described as 'a battle' between ministers. ${ }^{10}$ There were also other actors involved in the process, such as the various political factions in Northern Rhodesia, most notably the white settler lobby. This process was bound up in the crisis of decline in the late British Empire and the desire by colonial governments to increase control over businesses, which they considered vital to future economic development. We use these contestations to explore themes central to this Special Issue, including the obvert choice of firm nationality, the nature of the government-firm relationship in home and host countries, and how a change of domicile affects this dynamic. Further, the paper considers the role of white settlers in sub-Saharan Africa and their attempts to bolster a settler nationalism based around economic activity.

The central historiographical interpretation we develop is that the firms in this case were willing to jettison domicile in the UK in favour of closer alignment with the political power located in their country of operation, in this case Northern Rhodesia. In practical terms this was connected to the desire to reduce the financial burden caused by double-taxation. However, within the firms this was a gradual process of deliberative strategic decision-making. Our study also reveals how the firms in questions were only arguably "British" at the time of seeking to change 
domicile: they operated overseas, and were largely owned by American interests. Only among the senior management of the firm was there a more obviously "British" presence, though as we demonstrate the "American" strategic managerial influence was considerable-and ultimately prevailed.

The primary sources utilised in this article are chiefly drawn from the government records at the National Archives in London, the papers of Ronald Prain, managing director of the Rhodesian Selection Trust group from 1943, and its chairman from 1950-1972, at the American Heritage Center at the University of Wyoming, the papers of Selection Trust and related companies at the LSE in London, and relevant development oriented material in the Barclays Group Archives, in Manchester. The period covered in this article is relatively brief, beginning in 1950 when the firms began to internally discuss moving domicile, until 1953 when this was finally achieved. The article is structured as follows. First, we discuss how taxation relates to both nationality and imperialism, further connecting these concepts to ideas about sovereignty, and in turn how taxation becomes an important area of contestation and power as states seek to act in their national interest. This provides context around the issue of taxation. The second section provides political context by examining the politics of the emerging whitesettler dominated colony. The third section explores the organizational context of the RST group, examining issues of ownership and control. The fourth section then examines the development of RST's strategy with reference to the issue of switching domicile, and the fifth section examines the government discourse with reference to the same. The final empirical section explores the "end-game" of the process of RST's change of domicile. We conclude by relating the narrative, 
interpretation and argument development to the debate of the Special Issue and the implications for future research.

\section{Nationality, imperialism, sovereignty and taxation}

A feature of imperialism is the extra-territorial exertion of power by a nation-state over another territory or polity in such a way to subordinate that territory and/or polity to the imperial power. ${ }^{11}$ In contrast, sovereign statehood has been defined as 'a system of political authority based on territory, mutual recognition, autonomy, and control. ${ }^{12}$ Very clearly, then, territories that are subject to imperial powers are incapable of the 'ideal type' of sovereignty as identified above. However, in practice ' $[t]$ here has never been some golden age for sovereignty. The sovereign state model has always been a cognitive script; its basic rules are widely understood but also frequently violated. ${ }^{13}$ In the context of decolonization at the end of the British Empire it is therefore useful to think of how late-empire colonial states were able to accrue to themselves powers that independent states would usually have, and how this might cause friction or conflict between the metropole and the periphery. In highlighting this we build on existing historical literature led by White's (2000) critique of Cain and Hopkins (2000) that shows that the interests and strategy of companies diverged sharply from British colonial policy after 1945, with corporate interests, already long alienated socially from the political and military elites, sometimes finding themselves hedging on the side of decolonisation. ${ }^{14}$ White's work on the rubber industry in Malaya suggests that there was little cogency between the policies of British rubber companies and the British government despite the high profile Malayan 'emergency', and the British 
military intervention there, allowing British agency houses to cling on in Malaysia until the early 1980s. ${ }^{15}$ As we explore in more depth below, the Northern Rhodesian case was a little different. The white settler minority attempted to maintain its own power status, while "British" firms sought to exploit the situation by attempting to play the interests of the British state off against those of the settlers. ${ }^{16}$

Taxation was one such zone of interaction where different interests competed for fiscal or financial advantage. Taxation and domicile relate directly to control and to the broader institutional context for specific businesses. ${ }^{17}$ The operations of those businesses must necessarily have implications for economic development, economic policy, local control, and national politics (especially when in sensitive or important areas of the economy, as was the case for copper mining in Northern Rhodesia). Therefore understanding the historical dynamics of the relationship between decolonization, national and imperial politics, and corporate strategy, in relation to international taxation is an important and underresearched question in imperial history and business history to which we contribute here. Taxation is a contested terrain, as states variously seek to extract economic rents in order to pay for themselves and potentially control economic assets or to attract inward investment and boost economic growth. ${ }^{18}$ Tax regimes reflect differing priorities, and at the level of political discourse, can create tensions both within and between states, as different actors seek to pursue different agendas through taxation policy and the application of policy in practice. ${ }^{19} \mathrm{~A}$ particular problem for firms is the issue of international double taxation, where two states simultaneously tax the same corporate income or profits. The competing claims stem from the international separation of domicile and operation. ${ }^{20}$ This 
particularly affected FSCs reliant on capital-intensive host country activities as they sought to repatriate their profits. ${ }^{21}$

As Stockwell (2004) highlights, building on studies by Fieldhouse (1994), Wasserman (1976), and Leys (1975), the contest for statehood in Africa and Asia was mirrored by a contest for corporate domicile that did not necessarily reflect the interests of the metropole (i.e., the United Kingdom), which companies understood was in retreat in the post-war period. ${ }^{22}$ Stockwell argues-based on an analysis of policy-that British colonial governments 'frequently regarded double taxation arrangements as unsatisfactory in practice'. ${ }^{23}$ Stockwell further observes that this led to tensions between the different component actors in the colonial relationship, something also noted by Mollan and Tennent. ${ }^{24}$ The article by Mollan and Tennent colligates a large number of examples that are woven together into a historical interpretation of the role that international taxation plays in the disappearance of British FSCs. Their approach was confined to linked examples of firm behavior, so their article offers limited insight into interior management decision-making processes. Whereas they provide a credible account of the general pattern, the contribution of this article is to look more closely at insidethe-firm decision-making, as well as governmental and political factors that were at work.

The contest over the domicile of companies, and indeed their ability to switch residence, was shaped by the domestic UK policy-framework that had been created by the 1950 s to control corporations in terms of tax and domicilespecifically Section 468 of the Income Tax Act 1952. During the Second World War regulations were imposed via the Defence (Finance) Regulations Act, 1939 requiring Treasury approval for any firm wishing to change domicile or location 
of management, something that was then reinforced via Section 20 (2) of the Exchange Control Act, 1947. According to the Treasury, 'this control was introduced not for tax reasons but primarily to prevent foreigners gaining a controlling interest in companies then owned by United Kingdom residents'. ${ }^{25}$ Nevertheless, from 1915 onwards the Inland Revenue had monitored where companies had migrated managerial control abroad. However, it was only in 1950 that there was an 'increasing tendency' for firms (many of which were FSCs) to move their location of management abroad, something that 'began to arouse serious official concern. ${ }^{26}$ Though the Inland Revenue, Treasury and Bank of England disliked this trend, there was initially no desire to enact legislation to prevent this. However, in October 1950 the Anglo-American group of mining companies - then essentially an interlocking network of FSCs - announced that they were to move their domicile and management to South Africa, a decision that was publicly associated with taxation savings. So while in late 1950 the Inland Revenue continued to believe that 'nothing effective could be done ... to prevent the transfer of companies abroad' without seeking new powers from Parliament, by April 1951 this changed, leading to the Section 36 of the Finance Act 1951. This then became the Section 468 of the Income Tax Act $1952 .{ }^{27}$ The reason for this legislation was 'the protection of the revenue', which is why the cases that were rejected tended to be made on ground of pure and egregious tax saving/avoidance. ${ }^{28}$

The political context: Northern Rhodesia and settler politics before decolonization 
Historically, the economic importance of copper mining to the regional economy meant that it was of strategic importance when the issue of closer association between Northern Rhodesia (Zambia from 1964) and Southern Rhodesia (simply Rhodesia from 1964, and eventually Zimbabwe from 1980) and Nyasaland (Malawi after 1964) came into focus after WWII. In contrast to the trustee relationship between Colonial Office and colonies elsewhere in sub-Saharan Africa, in central Africa the presence of white settlers changed the dynamics of local power. The Southern Rhodesian settlers had successfully campaigned for greater control of local policy in 1923 and this saw the subsequent formalisation of colour bar practices, land alienation, and the expansion of 'native reserves' ${ }^{29}$ In Northern Rhodesia, the power of the so-called 'unofficials' (unelected, universally white) members of the Legislative Council meant the local colonial administration often bowed to their will. The generally accepted tenet that the Colonial Office, and its local representative (the Governor) should retain a majority in local decision-making bodies 'was in fact gradually whittled away as Governors and senior officials bent their policies to meet the strong and constant pressure of local European opinion.' ${ }^{30}$ Butler (2007) argues that after 1948, a convention was adopted that the Governor should follow the agenda set by the unofficials. In essence, this handed decision-making on certain issues to settlers. After this, it became 'prudent for the mining companies to be sensitive towards key settler political aims which included ...the continuing loss of mining revenue overseas. $^{31}$

A strong settler lobby led by Sir Godfrey Huggins, Prime Minister of Southern Rhodesia, and Roy Welensky, leader of the unofficials on Northern Rhodesia's Legislative Council, initially campaigned for the political 
amalgamation of the Rhodesias (essentially giving Northern Rhodesia with the same rights as Southern Rhodesia gained in 1923). ${ }^{32}$ The British Government denied this on the grounds that it would abrogate their responsibility to the welfare of Northern Rhodesia's African population. ${ }^{33}$ The settlers then pushed for a federal scheme to bring the Rhodesias together (the inclusion of Nyasaland was the idea of the British Government). ${ }^{34}$

The white settlers of the Rhodesias had pushed for closer association to maintain their privileged position in central Africa. Settler nationalism here was clearly defined by race, and, although falling short of the South African apartheid system, the colour bar existed in the Rhodesias especially in industrial sectors such as railways and mining, including the copperbelt. ${ }^{35}$ In these sectors the white working class settlers and their unions forced restrictions on occupations and levels of pay for African workers. Welensky himself had worked as a train driver and had formed the Rhodesian Labour Party in $1941 .{ }^{36} \mathrm{He}$ was determined that settlers' rights would not be challenged in favour of cheaper African labour. ${ }^{37}$

The Federation of Rhodesia and Nyasaland (known also as the Central African Federation; CAF) was created in August 1953. This Federation included Northern Rhodesia and Southern Rhodesia, as well as Nyasaland. Though Southern Rhodesia politically dominated the Federation, it was the Northern Rhodesian copperbelt that was expected to be the main export earner, and the economic dynamo of the new federal territory. ${ }^{38}$ Copper mining in Northern Rhodesia had expanded rapidly from the 1930s onwards and in the immediate post-war years the Copperbelt was one of the world's largest sources of copper ore. ${ }^{39}$ Production of refined copper in the territory stood at 138,000 tons in 1936 and had increased to 183,000 tons by $1946 .{ }^{40}$ As one of the most valuable 
commodities produced in the region, copper was very important to Britain's dollar earning/saving policy, especially after the convertibility crisis in 1947, and it determined British policy in the region. However, problems of fuel supply and infrastructure impinged on the Copperbelt's productivity. In 1949 the Colonial Office informed the Cabinet Committee on Colonial Development (CCCD) that poor availability of coal in the region was holding up the expansion of copper production. ${ }^{41}$ The only coal supply came from the Wankie (Hwange) Colliery in neighbouring Southern Rhodesia, over six hundred miles away. The main problem was the slow production of coal at the colliery and the poor rail link between the two areas. ${ }^{42}$ Development planners at the Colonial Office argued for improvements due to copper's importance as a "dollar earner and dollar saver" in the post 1947 economic climate. ${ }^{43}$ Northern Rhodesia produced 213,000 tons of refined copper in 1948 and 250,000 tons in 1949 , but supply commitments to the Union of South Africa, India, Australia, and Sweden, meant that the balance available was far short of British requirements for domestic needs. The Colonial Office argued that any shortfall in British imports of Rhodesian copper would necessitate imports from hard currency areas and all effort should be made to increase production. ${ }^{44}$ By 1955 copper made up 94\% of Northern Rhodesia’s exports and was $64 \%$ of the value of exports from the CAF. ${ }^{45}$ The planned development of Northern Rhodesia, and by extension the CAF, was centred on the copperbelt.

\section{The organizational context: the structure of the RST Group, c.1950-53 ${ }^{46}$}

Two groups of FSC like structures dominated the copper industry in Northern Rhodesia: Anglo American, and the Rhodesian Selection Trust (RST). ${ }^{47}$ RST had 
its origins in the Selection Trust group of companies that had been formed by the mining investment magnate Chester Beatty in the early 20th Century. By the time of the events described here, the core of the group consisted of both mining companies, on paper free-standing companies registered in the UK, and mining finance/holding companies that held investments in a complex of cross-owned assets (see Table 1 and Figure 1). It is commonly stated that the American Metal Company (AMCO) controlled $\mathrm{RST}^{48}$, though in fact both its governance structure and ownership structure reveal a more complex picture than the notion of a straightforward hierarchical relationship between the two.

Table 1. Capital structure of the RST group, c.1951.

\begin{tabular}{|c|c|c|c|c|c|c|}
\hline & Status & Incorporation details & Equity Capital & Debt Capital & $\begin{array}{l}\text { Equity held in } \\
\text { the UK (debt } \\
\text { held in the UK) }\end{array}$ & $\begin{array}{l}\text { Equity held } \\
\text { abroad } \\
\text { (debt held } \\
\text { abroad) }\end{array}$ \\
\hline $\begin{array}{l}\text { Rhodesian } \\
\text { Selection } \\
\text { Trust Ltd }\end{array}$ & Public Co. & $\begin{array}{c}\text { Incorporated in the } \\
\text { UK in } 1928\end{array}$ & $£ 5.2$ million & $\mathrm{N} / \mathrm{a}$ & $41 \%$ & $59 \%$ \\
\hline $\begin{array}{l}\text { Rhodesian } \\
\text { Selection } \\
\text { Trust } \\
\text { (Services) Ltd }\end{array}$ & Private Co. & $\begin{array}{l}\text { Incorporated in } \\
\text { Northern Rhodesia } \\
1951\end{array}$ & $£ 5,000$ & $\mathrm{~N} / \mathrm{A}$ & $100 \%$ & $0 \%$ \\
\hline $\begin{array}{l}\text { Mufulira Copper } \\
\text { Mines Ltd }\end{array}$ & Public Co. & $\begin{array}{c}\text { Incorporated in the } \\
\text { UK } 1930\end{array}$ & $£ 8.1$ million & $£ 0.7$ million & $32 \%(100 \%)$ & $68 \%(0 \%)$ \\
\hline $\begin{array}{l}\text { Roan Antelope } \\
\text { Copper Mines } \\
\text { Ltd }\end{array}$ & Public Co. & $\begin{array}{c}\text { Incorporated in the } \\
\text { UK } 1927\end{array}$ & $£ 8.9$ million & $£ 1$ million & $31 \%(100 \%)$ & $69 \%(0 \%)$ \\
\hline $\begin{array}{l}\text { Chibuluma } \\
\text { Mines Ltd }\end{array}$ & Public Co. & $\begin{array}{c}\text { Incorporated in } \\
\text { Northern Rhodesia } \\
1951\end{array}$ & $£ 0.6$ million & $n / a$ & $100 \%$ & $0 \%$ \\
\hline
\end{tabular}

Source: NA T233/2161 Document: 'Rhodesian Selection Trust and Associated Companies' (n.d).

Figure 1. the organizational structure of the RSt Group, c.1950-53. 


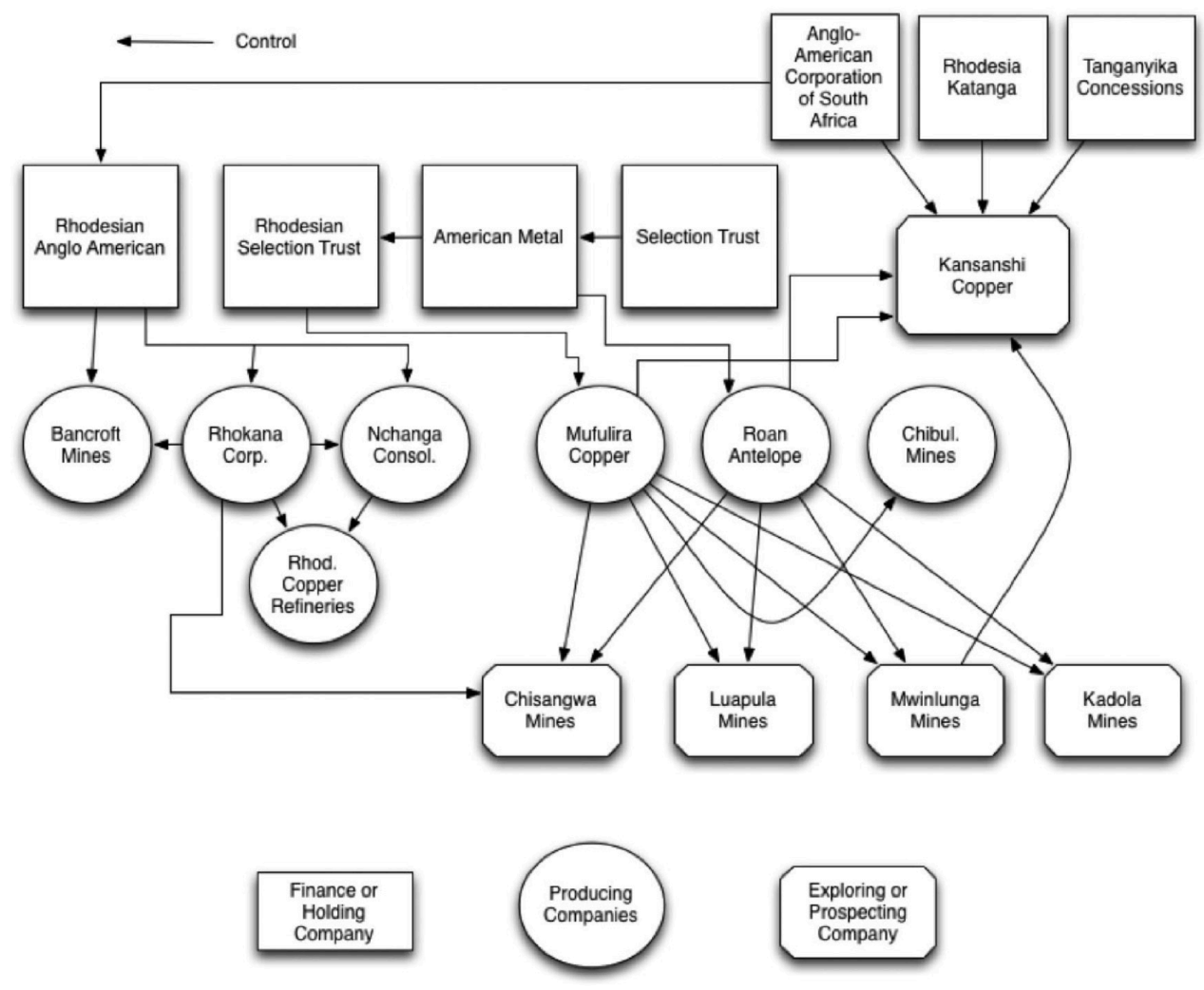

Figure 1 shows the nature of corporate control as diagrammatised by Ronald Prain in the Financial Times in 1951. This demonstrates that though American Metal was a significant influence, the London based Selection Trust also was an important controlling holding company. Nonetheless, as Table 1 makes clear, the capital ownership of the group was generally (c. two thirds) held overseas, in point of fact in the United States, with the UK Treasury commenting that both the RST group and the Anglo-American group 'are controlled, or can be controlled, from the United States. ${ }^{49}$ The American Metal Company had first invested in the RST group in the 1920s, and by the 1950s owned a controlling proportion of the equity capital. ${ }^{50}$

This then raises questions as to what constitutes a "British" company (or indeed the national designation multinational company) in the first place? If the site of the headquarters, and corporate registration, (in the case London) is 
different to the site of management and operations (Northern Rhodesia), which in turn is different to the chief locus of capital ownership and in this case potential control (the United States), then at one level we might consider that we cannot meaningfully consider a firm to have national qualities at all (it might simply be described as a transnational firm). This said, however, it was clear in both the developmental, economic and decolonization context of Northern Rhodesian (and by extension the CAF), and the political and fiscal position of the United Kingdom, that the extent of sovereign control over the firms in question was of considerable importance, and this in turn came to shape the political and business discourse around switching domicile.

\section{RST-AMCO Strategy}

The first question to ask is: why did the corporations wish to move domicile? Aside from the contextual increase in the burden of double taxation in this period ${ }^{51}$, those involved in setting the strategic direction for the company held different views that had emerged over time. Immediately, following the switch of domicile of the Anglo-American group in 1950, the price of American Metal Company shares rose-which AMCO executives believed was based on the expectation that the RST group would follow suit and this would lead to an improved profit-earning position in relation to taxation. ${ }^{52}$ Ronald Prain-chairman of RST from mid $1950^{53}$-did not agree with that analysis of AMCO's share price, and wrote in reply that 'our opinion in the office is definitely hardening against moving [domicile] and we know that if we agree with you on this attitude, we are assured in advance of considerable support in the City where already in the more responsible circles there 
is beginning to be some underground criticism of the Oppenheimer [the family which dominated Anglo-American] attitude. ${ }^{54}$

Harold Hochschild, the President of AMCO, and Prain were agreed that double taxation had made a significant negative impact on the profits of the Northern Rhodesian companies. ${ }^{55}$ In a public hearing to the US Congress in early 1950 Hochschild described the system of tax treaty relief on double taxation as 'inadequate', noting that taxation resulted in profits being reduced by $\$ 0.75$ on a dollar for Roan Antelope earnings, and $\$ 0.71$ on the dollar for Mufulira earnings. Taxes were, he said, 'the greatest hazard and greatest handicap to American companies seeking to develop foreign mining areas. ${ }^{56}$ And, as early as January 1951 Prain had discussions with the Bank of England about the issue of changing domicile in relation to taxation. ${ }^{57}$ Nevertheless, at that time Prain believed that only operational management could be properly conducted from Northern Rhodesia, the implication being that strategic management had to be located in London. ${ }^{58}$ Hochschild, however began to lay out a range of options for consideration to address the issue, including thinking about switching the head office to Bermuda-an emerging tax haven. ${ }^{59}$ Alongside Bermuda, they also considered New York, Ireland, Southern Rhodesia and Northern Rhodesia. ${ }^{60}$ Prain wrote to Hochschild dismissing both Bermuda and New York out of hand as 'wasting time'. 'These would be considered tax evasions with no possible pretence that the efficiency of the companies would be increased by such moves', he wrote. 'Any suggestion of such moves', he concluded '[would] in the present political climate be considered frivolous and would be refused outright.' ${ }^{61}$ So, while Prain's view was more circumspect, by mid-1951 the AMCO position was that a domicile in Northern Rhodesia would be preferable. ${ }^{62}$ 
Prain's view began to shift from mid 1951 onwards. First of all, proposed changes to legislation relating to government control over the ability of corporations to shift domicile evidently caused consternation in the mining sector as a whole. The British Overseas Mining Association-a special interest group chaired by Prain-was engaged in lobbying against the powers proposed in the bill that led eventually to Section $468 .{ }^{63} \mathrm{He}$ considered the bill to be 'the first departure in the field of business freedom from the basic principles of Magna Carta. ${ }^{64}$, which-while perhaps overly dramatic-indicates the skepticism that some quarters of the business community had in relation to the post-war Labour government. Prain was scathing in his assessment:

It is impossible to retain any respect for a government which acts in this way. ... Government Departments we have talked to appear to assume that the Bill merely seeks to make it statutory to obtain Treasury consent and that such consent would be forthcoming. It is difficult to follow this reasoning because, in that case, why produce a Bill at all ${ }^{65}$

Notwithstanding this, at this time Prain was against shifting domicile on tax grounds, writing that 'we still have no recommendation other than we should stay here [in the UK].'66

Hochschild took a different view. 'May it not be wiser', he wrote, 'to move while [the] gate [is] still open and deal now with grave practical problems rather than be forced to try to do it in two or three years meantime having lost several million pounds in double taxation'? ${ }^{67}$ Across the Autumn of 1951 the two men continued the discussion about the optimal course of action. Eventually Prain 
shifted his position, at face value based on two changing political contexts. The first was in the UK. Reflecting on the impending General Election in the Autumn of 1951, Prain wrote that 'if a Labour government is returned, it will be prima facie reason for seeking to change domicile, although it may be very difficult to effect, whereas if a Conservative Government is returned this be a prima facie reason for staying in England, although probably it will be easier to move domicile'. ${ }^{68}$ The reason he gave being that he expected the regulations relating to domicile switching to be slackened in the event of a Conservative government. ${ }^{69}$ Though a Conservative government was elected in October 1951, it did not result in the regulations changing. The second reason was related to the politics in Northern Rhodesia:

The most important of the factors is the future political set-up in this territory. We took our stand on domicile last year on political grounds, and have no reason to think that we were wrong. The political position seems to us to be of extreme importance, and to over-ride the tax considerations, which are important in the short-run but not always in the long-run. .... it would achieve nothing to move domicile and save taxes for three or four years only to find as a result of political changes here to which we were then committed, the Mines might be nationalised and lost to us. ${ }^{70}$

Prain ultimately concluded that any scenario in which a Conservative government was elected, and amalgamation towards CAF was to occur, would lead to the RST group switching domicile. ${ }^{71}$ By November of 1951 Prain appeared to confirm this change of position to Hochschild, stating that 'political events may now move in a 
direction where our views on domicile (which have been based predominately on political considerations) will no longer be in conflict with yours'. ${ }^{72}$

The boards of Roan Antelope, Mufulira, and RST agreed the policy of seeking to switch domicile in January $1952 .{ }^{73}$ At the Annual General Meeting of RST Prain publicly noted the change in direction, stating that:

Events appear to be moving rapidly towards a shift in the centre of political gravity for Northern Rhodesia affairs from the United Kingdom to Rhodesia. Such a change in the political picture may well create conditions under which we should consider it our duty both to our shareholders and to our country of production, and indirectly to the Commonwealth, to seek to locate our seat of control in Central Africa. ${ }^{74}$

Prain located the critical moment in the change in political gravity as being the Victoria Falls Conference in September 1951, at which the British government invited representatives of the Rhodesias and Nyasaland to consider the draft proposals for federation produced by Colonial Office and Commonwealth Relations Office. ${ }^{75}$ Equally, however, it was acknowledged that there would be a taxation advantage to migrating, though the board were at pains to stress that the decision to attempt to migrate was not solely about taxation, something that had previously brought the board into dissonance with the shareholders who had wanted an earlier switch to save tax. ${ }^{76}$

The Treasury were sceptical, stating that '[t]he companies have a total capital of nearly $£ 30$ million and very large reserves. Their businesses have expanded rapidly and continuously and it cannot reasonably be claimed that their 
progress has been hampered by United Kingdom taxation. ${ }^{77}$ Prain argued to government that reducing taxation was a relatively minor factor. ${ }^{78}$ Speaking candidly to Julian Crossley, Chairman of Barclays (Dominions, Colonies, and Overseas), in January 1951, Prain said that that savings on the transfer of domicile for Roan Antelope would be much less than commonly expected, not amounting to more that $£ 100,000$ on the previous year's figures. ${ }^{79}$ However, the Treasury thought that this was 'difficult to believe' and that the announcement of the Excess Profits Levy (a Labour government tax which aimed to encourage reinvestment of profits into new production $)^{80}$ had 'quicken[ed] the directors' appreciation of the political factors calling for transfer. ${ }^{181}$ The Colonial Office further believed that the transfer would aid development of the colony, something that the Treasury also wanted, in particular by attracting American capital. ${ }^{82}$

Within RST the corporate discourse was concerned with both tax saving and getting ahead of likely political changes associated with the process of semidecolonization and federation. At the Annual General Meeting of the RST Ltd. on 14 December 1950 Ronald Prain said that 'the tax savings which would accrue on transfer abroad, while substantial, cannot necessarily be regarded as permanent and are not in themselves a sufficient reason for abandoning our conception of how a Colonial mining enterprise should be conducted.' Yet by 1952 he was to argue that 'a change in domicile would effect impressively large savings in taxes for the company. ${ }^{183}$ Writing early that year to the American parent company (AMCO) Prain noted that 'it is unlikely that permission to move control would be granted today ... [but] it will be difficult not to grant it after Federation talks." ${ }^{84}$ Within AMCO, however, the discourse was clearly around achieving a taxation saving, 
whereby a 'change of domicile will give us complete relief from multiple taxation ... [this will be] of material benefit to AMCO" 85

\section{Government and politics}

The political considerations themselves turned on two main elements, the first connected to domestic Northern Rhodesian political development through federation, and the second in relation to the likely drivers of economic development in relation to the sources of capital for investment. ${ }^{86}$ In this respect, the Treasury took a view which reflected the diminished economic and political status of Britain in the wider world:

[I]t is the policy of Her Majesty's Government to welcome the investment of American capital in the Commonwealth, in particular, on the conditions that it will be permanent and dollar earning or dollar saving. ${ }^{87}$

The Treasury further believed that the Northern Rhodesian mining groups would get the capital investment they needed to expand production from the United States, and that they would do so 'more easily and cheaply if both [groups: AngloAmerican and RST] are resident in Northern Rhodesia. ${ }^{188}$

The decision whether to allow RST to switch domicile was therefore not only about the impact of the corporation itself switching domiciles, or the perceived benefits and costs to business and the Northern Rhodesian/CAF economy, but also to the perception in London that allowing RST to switch would open the floodgates to similar switches, to the cost of the British tax base. 'It is arguable', one Treasury official wrote, 'that if these companies are allowed to 
migrate it will be virtually impossible to prevent anybody else of any importance from doing the same in future. ${ }^{189}$ The Treasury were concerned both with the wider impact that this would have on revenue, estimated to be perhaps as much as $£ 100$ million per year, but also to its impact on the City of London as a financial and commercial centre:

There are obvious advantages to the United Kingdom in companies having their "seat of management" here. The profits, the products, contracts for new equipment, shipping and insurance services, etc., all tend as a result to be dealt with through London; whereas once a company's headquarters are moved, the link with London becomes progressively weaker and local feeling sometimes tends to turn against the absentee owners. ... In some respects, London as the financial centre of the Commonwealth is in a state of decline, and not only in the sense that the London market can no longer meet all calls upon it for finance. Many companies have left or are leaving and nothing is coming from overseas to take their place. ${ }^{90}$

The Colonial Office was 'frankly hostile' to Section 468 believing that a 'change of residence [would] be beneficial to the Colony concerned' and would also attract capital into the colonies, in particular from the USA. ${ }^{91}$ The Bank of England were similarly opposed to Section 468 , stating that '[v]ery few companies ever want to move their headquarters to countries outside the Sterling area and those that do usually do so for pretty serious reasons, e.g. compliance with the nationalistic aspirations of the host country, which we hardly dare to resist'. ${ }^{92}$ The Bank of 
England and Treasury were sceptical of reducing the freedom of movement within the Sterling Area, arguing that it would have negative consequences for the City:

[I]t would in the long-run strike at the root of London as a financial centre for international business, that it would provoke existing business who would otherwise have been content to remain here to seek permission to migrate before worse befell, and that it would positively discourage any new businesses who might have been thinking of making their headquarters in London from doing so. ${ }^{93}$

A later Treasury memorandum put the issue even more starkly:

In the old days there had been some advantage in registering a mining company in the City of London where it had available financial facilities and the services of the shipping companies. In present circumstances no one of sound mind would set up a new company in this country to extract minerals in the colonies-they would have all the profits taken by the United Kingdom Exchequer and would be subject to meticulous and unreasonable control in regard to the raising of capital and the like. ${ }^{94}$

The report argued that this amounted to a form of 'colonial exploitation' that was more 'severe' than any that had existed in the past. In the context of growing awareness of the problems of colonialism, and in the midst of wider moves towards decolonization, this reveals the way in which the economic ministries of the British 
government considered the imperial role that business ought to play in empire, and the benefits that it should accrue..$^{95}$

So it was that the specific issue of the Selection Trust companies was heavily bound up with issue of high policy at a moment of both economic and imperial decline. In fact, though Section 468 and previous measures had been in existence since the late 1930 s, for 501 applications to transfer residence, as table 2 shows, only nine had ever been refused. ${ }^{96}$ Where companies were rejected it was largely connected to being mainly motivated by a taxation reductions. ${ }^{97}$

Table 2. Corporate transfer of residence 1915 - 1952.

\begin{tabular}{lcc}
\hline & Applications & Consent Refused \\
\hline Transfers of management and control & 23 & 3 \\
Transfers of businesses or parts of businesses & 233 & 5 \\
Issues of shares by overseas subsidiaries & 184 & 0 \\
Transfers of shares in overseas subsidiaries & 61 & 1 \\
Total & 501 & 9 \\
\hline
\end{tabular}

Source: NA T233/2162 Memo on S. 468 Income Tax Act, 1952.

The Inland Revenue took the view that if the Selection Trust was given permission to transfer residence, it would open the floodgates and lead to the effective end of the powers enshrined in Section $468 .{ }^{98}$ They noted that the transfer of management in firms to Northern Rhodesia in 1950 had by 1952 led them to seek to transfer the whole registration, and that 'the transfer of the seat of management and control tends to only the first step on a rather slippery slope. ${ }^{199}$ The Treasury in contrast were clear that it would be to the benefit of the Sterling Area if companies were free to move within it as they liked, but against this was weighed the impact on the City and the loss to tax revenue. Here, the issue of colonial development did not count for much against income concerns: 'even the "development" considerations 
cannot be said to be so important or certain as to outweigh the need to safeguard such an amount of revenue.' ${ }^{100}$ The argument put forward by the Colonial Office, Northern Rhodesian government, and by Welensky on behalf of the white labour unions was that it was of 'practical importance to have these enterprises domiciled on the spot.' ${ }^{101}$

At the local level, Northern Rhodesia's strong settler lobby, led by Welensky, had effectively gambled that federation would preserve the status of white settlers in the Rhodesias. For Welensky and Godfrey Huggins, Prime Minister of Southern Rhodesia, federation needed to prove itself quickly to the British Government, where scepticism about the scheme among liberals was still high. ${ }^{102}$ Welensky wrote to Ronald Prain in May 1952 to indicate the settler perspective of seeking more local control by the colonial state. 'I do not think it is satisfactory', he wrote 'that Companies which contribute largely to Northern Rhodesia's revenue should be controlled from outside the territory, nor that the Boards of such large employers of labour within the territory should not be readily available for consultation by the Government. ${ }^{103}$ The Colonial Office wrote of Welensky that 'one never quite knows whether Mr. Welensky is in Government or in Opposition. He is certainly an avowed opponent of "Whitehall rule". He is a bit self-important and rather touchy but susceptible to flattery. ${ }^{104}$ Welensky may have played a key role in changing Prain's mind on the domicile issue after a visit by Prain to Rhodesia in the first half of 1952, prior to the May application to transfer residence, probably connected to the potential for more harmonious managementlabour relations if the firm were managed locally, a point that Welensky made in person to the Chancellor of the Exchequer in January 1953.105 


\section{The end-game}

By December 1952 Ronald Prain had become impatient and had contacted the Treasury to find out why the decision on allowing the companies to move was not forthcoming. ${ }^{106}$ Shortly after the Colonial Office wrote to R. A. Butler, the Chancellor of the Exchequer of the United Kingdom, to exert similar pressure on the Treasury for the relative slowness of the decision, explaining that both Prain and Welensky were concerned that no decision had been made. ${ }^{107}$ In fact the Advisory Panel under Lord Kennet (then Chairman of the Capital Issues Committee of the UK Treasury) had made their recommendation in favour of allowing the transfer by October of 1952, writing to the Revenue asking them to drop their objections. ${ }^{108}$ However, the Treasury remained unsure of how to proceed:

The loss of revenue apart, it is in general a matter for regret that so many enterprises created or established in the United Kingdom should find it necessary, or at least advantageous, to move their seats of control and management elsewhere. Where the desire to migrate generally arises from other causes than the weight of UK taxation, it is probable (ignoring the loss of revenue) that the least damage would be done to the interests of the United Kingdom by allowing companies to pursue their own best interests. But where the principle [sic] motive for migration is the avoidance of tax, the matter assumes a different aspect. ${ }^{109}$ 
As the report noted 'both motives are frequently at work in the one case' and 'the decisive motive cannot be objectively determined but it can be inferred'. This placed the UK government in the slightly unusual position of trying to judge strategic motivation, but where under the legislation-designed to preserve revenue-the weight of taxation being the main concern. ${ }^{110}$

One initial option the Treasury considered was to just allow Chibuluma Mines Limited to migrate because the Inland Revenue had no objections, largely because it generated no tax income for the revenue. ${ }^{111}$ The Treasury clearly believed that the loss to the revenue and the gain to the companies-by 1953 estimated to be $£ 5.5$ million per annum-that 'despite the group's denials' was 'a major factor behind the application. ${ }^{112}$ The government in Northern Rhodesia and the Colonial Office in London, however, remained of the opinion that all of the companies ought to be able to migrate. ${ }^{113}$ Eventually, by March 1953 that view prevailed, and the Chancellor of the Exchequer decided to allow all of the copper companies to transfer domicile. ${ }^{114}$ Oliver Lyttelton, the Colonial Secretary wrote to R. A. Butler to say he was 'very happy' about the decision, also commenting that he thought it was 'a major matter of imperial policy'. Scrawled in the margin, was one word: 'Hooray.'115

\section{Conclusions}

The core purpose of this SI is to examine the importance of "nationality" to corporations. The overarching interpretation that we have developed here is to emphasise how notions of nationality reflect and describe a political and economic terrain that corporations have to negotiate. This sits outside the firms themselves but comes to affect behaviour within firms, as they interact with the changing 
external environment. This article makes a number of contributions to the historical literature relating to both the nationality and internationality of the corporation.

First the sovereignty puncturing nature of international investment (and on the ground, international business) as part of imperial processes means that investment (the businesses) can become both a site of de-colonial conflict, and also a venue where broader structural changes in international political-economic power play out. With reference to the Selection Trust companies in CAF we see that in a number of ways. In the context of the 'periphery'-in the CAF-Welensky's settler nationalism led the colonial government to seek effective control of an economic asset of strategic importance to the viability of the CAF. In this way the "nationality" of the firm became important within that political discourse: if it was a "British" firm based in the UK then Northern Rhodesian political interests would have less power; if the company could move its domicile (change "nationality") then it would lead to an increase in power in that colony. This should not be seen as decolonization per se, but as disintegration as the settler colonialists sought to develop the economy and consolidate their power in their own interests.

Second, the ability of jurisdictions (which are aspects of sovereign power) to exert control over corporate entities is also of importance. Legislation passed to prevent corporate migration from the UK did not point to economic strength but to economic weakness, transferred to the policy domain as a defensive measure. The sense that the decline of Britain economically-particularly the decline of the City of London-marks both the structural inability of Britain to exercise its power imperially, and also explains why firms might want to move away from the UK. At the same time, the political bargains that corporations might strike locally (in a 
gradually decolonizing world) represents both the increase to sovereignty in those domains, and a structural shift away from British capitalist-imperialist power, to American capitalist power-which can be argued as imperialist also from a structural (and sometimes intentional) perspective also. Nevertheless, the ability of gradually decolonising states, such as Northern Rhodesia, to increasingly assert their sovereign power over the corporations that operated within their borders show how the "core" was withering and the "periphery" was increasingly able to take control. Within the process at the heart of government in the UK we see a contest for different views of the best ways to proceed in the (British) national interest, which is weighed against the needs of colonial development, tax revenue, and international politics. This guards against notions of monolithic unitary intent and synecdochical ways of describing the position of actors. It also speaks to the tensions and difficulties that the British government as a whole had to deal with at a moment of economic and imperial decline. Indeed, the concerns about the impact of taxation on British international business led to the creation of the Royal Commission on Taxation of Profits and Income that ultimately led to the creation of the Overseas Trading Company tax status for British overseas business, about which considerably more need to be known. ${ }^{116}$

Third, we turn to the corporations as actors in the process narrated here. Here we can see opportunism, a desire to align with the nascent political powers (in this case both the USA and the CAF, and away from Britain) and evidence of the footloose nature of capital. Here we understand being footloose in terms of the ability to shift domicile (clearly mines cannot move!). This was mediated by the need to articulate with, and integrate into, power structures that were defined nationally-including gaining access to "American" capital. It nevertheless also 
represents the ability of the RST group to adapt and mutate from a "British" business into something more "international" or, perhaps, to becoming more obviously "American", since the companies in question were subsidiaries of American corporations, at least nominally.

And fourth, this case also serves as an empirically evidenced example of the decline/disappearance of the British FSC, not only in terms of what happened to specific firms, but also what happened to this specific mode of international organization: it was from a place and moment in historical time that were declining and decaying respectively, a product of unique historical conditions that-in the changing international political-economy of the post-war and decolonizing worldno longer held a reason to exist. The City of London had become less attractive as a 'headquarters city' as the international capital markets for new international businesses diminished, and the networks of the professional and commercial services that had helped to create FSCs themselves gradually disappeared. ${ }^{117}$ International double taxation together with the political forces unleashed by decolonisation essentially encouraged the movement of domicile away from the metropole in the extractive industries that had accounted for so much of pre-1914 era international investment. In these conditions, the competitive advantage of the FSC organizational form-especially in international mining- had been critically undermined. Therefore, the interpretation made by Wilkins (1998) and Mollan and Tennent (2015) that the disappearance/decline of the FSC was caused (at least in part) by the impact of international taxation is essentially correct. By looking more deeply through a case study our contribution is to demonstrate how this was mediated by both political and governmental processes, and economic factors. As we also note in this article, a large number of other firms and subsidiaries changed 
domicile in the post-war period, but little is known about what factors influenced those changes. There is therefore substantial scope for new research to explore these additional cases, and in so doing helping to further address the historiography of the FSC, as well as to develop a theoretically robust account of the structural and spatial changes to the organizational forms of international business in the post-war period. 
${ }^{1}$ Sidney Pollard, "Capital Exports, 1870-1914 Harmful or Beneficial?," The Economic History Review 38, no. 4 (1985): 489-514; Michael Edelstein, "Foreign Investment and Accumulation, 1860-1914," in The Economic History of Britain since 1700, Volume Two: 1860-1939, ed. R. Floud and D. McCloskey (Cambridge: Cambridge University Press, 1994), 173-96; Lance Davis and Robert Huttenback, Mammon and the Pursuit of Empire: The Political Economy of British Imperialism, 1860-1912 (Cambridge: Cambridge University Press, 1986); Lance Davis, "The Late Nineteenth-Century British Imperialist: Specification, Quantification and Controlled Conjectures," in Gentlemanly Capitalism and British Imperialism, ed. Raymond E. Dumett (London: Longman, 1999), 82-112.

${ }^{2}$ Mira Wilkins, “The Free-Standing Company, 1870-1914: An Important Type of British Foreign Direct Investment," The Economic History Review, New Series, 41, no. 2 (1988), 259-82; Mira Wilkins, "The Free-Standing Company Revisited," in The Free Standing Company in the World Economy, 1830-1996, ed. Mira Wilkins and Harm Schröter (Oxford: Oxford University Press, 1998), 3-66; For an overview of the development of this concept in international business history see: Tom Houston and John H. Dunning, UK Industry Abroad (London: Financial Times, 1976); Stanley Chapman, "British-Based Investment Groups Before 1914," The Economic History Review 38, no. 2 (1985): 230-47; Simon Mollan, "The Free-Standing Company: A 'zombie' Theory of International Business History?," Journal of Management History 22, no. 2 (2018): 156-73.

${ }^{3}$ Ranald Michie, The City of London: Continuity and Change since 1850 (London: Macmillan, 1991); Simon Mollan and Ranald Michie, "The City of London as an International Commercial and Financial Center since 1900," Enterprise and Society 13, no. 3 (January 27, 2012): 538-87,; Kevin Tennent, "Owned, Monitored, but Not Always Controlled: Understanding the Success and Failure of Scottish Free-Standing Companies, 1862-1910” (The London School of Economics and Political Science (LSE), 2009).

${ }^{4}$ Rory Miller, "British Free-Standing Companies on the West Coast of South America," in The Free Standing Company in the World Economy, 1830-1996, ed. Mira Wilkins and Harm Schröter (Oxford: Oxford University Press, 1998), 218-51; Simon Mollan and David K. Kelsey, "An Overview of the Business History of the International Mining Industry," in Contemporary Issues in Mining, ed. Nigel Finch (Sydney: Palgrave Macmillan, 2012); Stanciu, "Free-Standing Companies in the Oil Sector in Romania and Poland Before 1948: Typologies and Competencies"; Tennent, "Owned, Monitored, but Not Always Controlled: Understanding the Success and Failure of Scottish Free-Standing Companies, 1862-1910"; Kevin Tennent, "Management and the Free-Standing Company: The New Zealand and Australia Land Company c . 1866-1900," The Journal of Imperial and Commonwealth History 41, no. 1 (March 2013): 81-97; David Boughey, "British Overseas Railways as Free-Standing Companies, 1900-1915," Business History 51, no. 3 (May 2009): 484-500; Simon Mollan, "Business Failure, Capital Investment and Information: Mining Companies in the AngloEgyptian Sudan, 1900-13," The Journal of Imperial and Commonwealth History 37, no. 2 (2009): 229-48; Charles Jones, "Commercial Banks and Mortgage Companies," in Business Imperialism, 1840-1930: An Enquiry Based on British 
Experience in Latin America, ed. D.C.M. Platt (Oxford: Clarendon Press, 1977), 17-52; Charles Jones, "Institutional Forms of British Foreign Direct Investment in South America," Business History 39, no. 2 (April 1997): 21-41; Stuart Jones, "Origins, Growth and Concentration of Bank Capital in South Africa, 1860-92," Business History 36, no. 3 (July 1994): 62-80; Geoffrey Jones, "British Overseas Banks as Free-Standing Companies, 1830-1996," in The Free Standing Company in the World Economy, 1830-1996, ed. Mira Wilkins and Harm Schröter (Oxford: Oxford University Press, 1998), 344-60; Robert G Greenhill, "Investment Group, Free-Standing Company or Multinational? Brazilian Warrant, 1909-52," Business History 37, no. 1 (1995): 86-111; Marilyn Gerriets, "The Rise and Fall of a Free-Standing Company in Nova Scotia: The General Mining Association," Business History 34, no. 3 (1992): 16-48.

${ }^{5}$ Wilkins, "The Free-Standing Company Revisited"; Mark Casson, "Institutional Diversity in Overseas Enterprise: Explaining the Free-Standing Company," Business History 36, no. 4 (1994): 95-108; Mark Casson, "An Economic Theory of the Free-Standing Company," in The Free Standing Company in the World Economy, 1830-1996, ed. Mira Wilkins and Harm Schröter (Oxford: Oxford University Press, 1998), 99-128; Jean-Francois Hennart, "Transaction-Cost Theory and the Free-Standing Firm," in The Free Standing Company in the World Economy, 1830-1996, ed. Mira Wilkins and Harm Schröter (Oxford: Oxford University Press, 1998), 65-98; T. a. B. Corley, "Free-Standing Companies, Their Financing, and Internalisation Theory," Business History 36, no. 4 (October 1994): 109-17.

${ }^{6}$ Wilkins, "The Free-Standing Company Revisited.".

${ }^{7}$ Simon Mollan and Kevin Tennent, "International Taxation and Corporate Strategy: Evidence from British Overseas Business, circa 1900-1965," Business History 57, no. 7 (2015): 1-28.

${ }^{8}$ NA T233/2162 'Mr Drake: Item 3 and Item 4', 12 February 1953.

${ }^{9}$ LSE Archives, SELECTION TRUST/2009/110 - Selection Secretariat Ltd Minute Book, 1943-1954, Minutes of 21st Board Meeting Held at the Registered Office on Thursday 18 June 1953; SELECTION TRUST/2009/44 - Board Meeting Minutes, 1950-1956, 217th Board Meeting, 5 February 1953; 222nd Board Meeting, 4 June 1953.

${ }^{10}$ NA T233/2161 Minute Sheet 'S. 468 Income Tax Act 1952: Rhodesian Selection Trust and Associated Companies', written by Mr. Hunter Johnson, 31 July 1952.

${ }^{11}$ Alexander J Motyl, Imperial Ends: The Decay, Collapse, and Revival of Empires (New York: Columbia University Press, 2013); Michael W Doyle, Empires (Cornell University Press, 1986).

${ }^{12}$ Stephen D Krasner, "Rethinking the Sovereign State Model," Review of International Studies 27 (2001): 18.

${ }^{13}$ Ibid., 17.

${ }^{14}$ N. J. White, The business and the politics of decolonization: the British experience in the twentieth century. Economic History Review 53, vol. 3 (2000), pp. 544-564. Cain, P. J. and Hopkins, A. G., British Imperialism, 1688-2000, (Harlow: London, 2001).

${ }^{15}$ N. J. White, 'Government and business divided: Malaya 1945 - 57', Journal of Imperial and Commonwealth History, 22 (May 1994). See also Nicholas J. White, 'Gentlemanly capitalism and empire in the twentieth century: the forgotten case of Malaya, 1914 - 1965' in Raymond E, Dumett, Gentlemanly 
capitalism and British Imperialism: The New Debate on Empire (London: Longman, 1999) pp. 184 - 188; S. Yacob and N. J. White, The 'Unfinished Business' of Malaysia's Decolonisation: The Origins of the Guthrie 'Dawn Raid', Modern Asian Studies, 44, no. 5 (2010), pp. 919-960.

${ }^{16}$ L. J. Butler Copper Empire: Mining and the Colonial State in Northern Rhodesia, c.1930 - 1964 (Basingstoke: Palgrave, 2007), pp. 202-203.

${ }^{17}$ The existing historical literature on changes to domcile is limited, but indicates that the context for changes varied considerably. For example one article indicates that Australia refused to allow a wholesale trading firm to relocate domicile from the UK to Australia in the 1970s because of insufficient equity holding in Australia. See Mollan, Simon. 2010. "S. Hoffnung and Co: The Case of a Market Intermediary in Australia, 1851-1980." Consumption, Markets and Culture 13 (1): 7-30. Dissimilarly, in Malaya in the 1970s, rubber firms were forced to change domicile as a result of government policy despite hostility from the board of directors. See Yacob, Shakila, and Nicholas J. White. 2010. "The 'unfinished Business' of Malaysia's Decolonisation: The Origins of the Guthrie 'Dawn Raid.'” Modern Asian Studies 44 (5): 919-60. What both articles reveal is that changes of domicile were contingent on political processes that had the capacity to frustrate the intentions of management.

${ }^{18}$ Lorraine Eden, Taxing Multinationals: Transfer Pricing and Corporate Income Taxation in North America (Toronto: University of Toronto Press, 1998); Lorraine Eden, "Taxes, Transfer Pricing and the Multinational Enterprise," in The Handbook of International Business, ed. Alan Rugman and Thomas Brewer (Oxford, 2001), 591-619; Anwar Shah and Joel Slemrod, "Do Taxes Matter for Foreign Direct Investment?," The World Bank Economic Review 5, no. 3 (1991): 473-91; Assaf Razin and Joel Slemrod, "Introduction," in Taxation in the Global Economy, ed. Assaf Razin and Joel Slemrod (Chicago: University of Chicago Press, 1990), 1-11; Mollan and Tennent, "International Taxation and Corporate Strategy: Evidence from British Overseas Business, circa 1900-1965"; Michael Ashley Havinden and David George Meredith, Colonialism and Development: Britain and Its Tropical Colonies 1850-1960 (London: Routledge, 1993).

${ }^{19}$ P. Profeta and S. Scabrosetti, The Political Economy of Taxation: Lessons from Developing Countries (Cheltenham: Edward Elgar, 2010); Martin Daunton, Just Taxes: The Politics of Taxation in Britain, 1914-1979 (Cambridge:

Cambridge University Press, 2007); Sol Piccotto, "Slicing a Shadow: Business Taxation in an International Framework," in Capitalism, Culture and Economic Regulation, ed. L. Hancher and M. Moran (Oxford: Clarendon Press, 1989), 1147; Roland Paris, "The Globalization of Taxation? Electronic Commerce and the Transformation of the State," International Studies Quarterly 47, no. 2 (2003): 153-82. Julie H Collins and Douglas A Shackelford, "Corporate Domicile and Average Effective Tax Rates: The Cases of Canada, Japan, the United Kingdom, and the United States," International Tax and Public Finance 2, no. 1 (1995): 55-83.

${ }^{20}$ For a discussion of the origins of double taxation see Rixen, Thomas. The Political Economy of International Tax Governance. Basingstoke: Palgrave Macmillan, 1998 Tennent (2015). For the development of taxation in Northern Rhodesia, see Butler, Copper Empire, 196-198.

${ }^{21}$ See Mollan and Tennent (2015), passim. 
${ }^{22}$ Stockwell, Sarah. "Trade, Empire, and the Fiscal Context of Imperial Business during Decolonization," Economic History Review 57, no. 1 (2004): 142-60; D. K. Fieldhouse. "Merchant capital and economic decolonization: The united Africa company 1929-1987." (Oxford: OUP, 1994); C. Leys, Underdevelopment in Kenya: The Political Economy of neo-colonialism. (London, Heinemann, 1975); G. Wasserman, Politics of Decolonization : Kenya, Europeans and the Land Issue, 1960-1965 (Cambridge: Cambridge University Press, 1976).

${ }^{23}$ Stockwell (2004), p.147.

${ }^{24}$ Stockwell, ibid; Mollan and Tennent (2015), p.1065.

${ }^{25}$ NA T233/2161 Draft Memo on S. 468 Income Tax Act, 1952, n.d.

${ }^{26}$ NA T233/2161 Draft Memo on S. 468 Income Tax Act, 1952, n.d.

${ }^{27}$ NA T233/2161 Draft Memo on S. 468 Income Tax Act, 1952, n.d.

${ }^{28}$ NA T233/2162 The Migration of Companies (S. 468 of the Income Tax Act, 1952), 20 January 1953.

${ }^{29}$ The British Government theoretically retained responsibility for Southern Rhodesia's 'Native Department', however, after the granting of 'responsible government' in 1923 the British government did not interfere with any legislation put forward. See Andrew Cohen, 'The politics and economics of decolonization in Africa: The failed experiment of the Central African Federation (London, I B Tauris 2017) pp.31 - 33; and Richard Gray 'The two nations: Aspects of the development of race relations in the Rhodesias and Nyasaland (Oxford: Oxford University Press, 1960) pp. $12-16$.

${ }^{30}$ Cranford Pratt, 'British Colonial Policy in Africa' in Colin Leys and Cranford Pratt (eds.), A New Deal in Central Africa (Heineman, 1960) p.42

${ }^{31}$ L. J. Butler Copper Empire: Mining and the Colonial State in Northern Rhodesia, c.1930 - 1964 (Basingstoke: Palgrave, 2007), p.202.

32 J. J. B. Somerville, "The Central African Federation," International Affairs Vol. 39, No. 3 (1963) pp. 387-389

${ }^{33}$ Sir Roy Welensky 'Welensky's 4000 days: The life and death of the Federation of Rhodesia and Nyasaland' (London, Collins: 1964), pp. 22-24

${ }^{34}$ Welensky 'Welensky's 4000 days', pp.21-44

${ }^{35}$ Murray Steele, 'Labour and the Central African Federation: Paternalism, Partnership and Black Nationalism, 1951 - 60' in Frank et al (ed.) The British Labour Movement and Imperialism (with Foreword by Tony Benn) (Newcastle upon Tyne: Cambridge Scholars, 2010) pp. 132-137, Cohen, 'The politics and economics of decolonization in Africa' p.6

${ }^{36}$ Cohen, 'The politics and economics of decolonization in Africa' p.57

37 'Sir Roy Welensky' [Obituary] The Daily Telegraph 06/12/1991 p.19

${ }^{38}$ L. J. Butler Copper Empire: Mining and the Colonial State in Northern Rhodesia, c.1930 - 1964 (Basingstoke: Palgrave, 2007), p.210

${ }^{39}$ L. J. Butler, "Business and British Decolonisation: Sir Ronald Prain, the Mining Industry and the Central African Federation," The Journal of Imperial and Commonwealth History 35, no. 3 (September 2007): 460.

${ }^{40}$ NA CO852/868/1 Colonial Economic Development Council (CEDC) Papers and Minutes - Draft Interim Report of the Colonial Development Working Party 1948.

${ }^{41}$ NA CAB/134/66 Colonial Office Memo to CCCD 'Coal for the Copperbelt in Northern Rhodesia', 17 September 1949. CAB/134/66; Catherine

Schenk, Britain and the Sterling Area - From devaluation to convertibility in the 1950's. London: Routledge, 1994, pp. 8, 35 - 41; Tomlinson, Jim. Managing the 
Economy, Managing the People: Narratives of Economic Life in Britain from Beveridge to Brexit. Oxford: Oxford University Press, 2017, pp.206-213.

${ }^{42}$ Barclays Group Archive (BGA) ACC 80/3671 'Chairman's notes on Rhodesian visit February/March 1950'. On a visit to the Rhodesias in 1950, Julian Crossley, Chairman Barclays DCO, noted that the dramatic rise in white immigration to Southern Rhodesia since the war had seen the population double since in 1939. He believed this was a contributory factor to the colonies slow economic progress due to the increased demand on resources. This was demonstrated by the principal municipal power station which regularly had only 24 hours supply of fuel on hand.

${ }^{43}$ NA CAB/134/66. Colonial Office Memo to CCCD 'Coal for the Copperbelt in Northern Rhodesia', 17 September 1949.

${ }^{44}$ NA CAB/134/66 Minutes of CCCD Meeting, 13 January 1950.

${ }^{45}$ BGA ACC80/3624 'The position of copper in the federal economy', speech by R. L. Prain, O.B.E at the Bulawayo National Affairs Association, 22 May 1956. ${ }^{46}$ Source: The Financial Times, 1 June 1953, 1. Article by Ronald Prain, 'The Growth of the Copperbelt in Northern Rhodesia'.

${ }^{47}$ Butler, "Business and British Decolonisation: Sir Ronald Prain, the Mining Industry and the Central African Federation," 460.

${ }^{48}$ Butler, Copper Empire, passim.

${ }^{49}$ NA T233/2162 'Note of Reasons for the Advisory Panel's Recommendation' by R.H. Binder, 23 October 1952.

${ }^{50}$ American Heritage Centre (AHC), University of Wyoming, Ronald AHC Prain Papers, 8753-84-09-17 (hereafter AHC AHC Prain Papers), Box 1, File AMCO. Harold K. Hochschild Correspondence, 1950-1951, Statement of Harold Hochschild (hereafter Hochschild), Chairman and President of The American Metal Company, Ltd - Submitted to The Committee on Ways and Means House of Representatives, Friday February 10, 1950.

${ }^{51}$ Mollan and Tennent, "International Taxation and Corporate Strategy: Evidence from British Overseas Business, circa 1900-1965."

52 AHC Prain Papers. Box 1. File AMCO. Hochschild Correspondence, 19501951, Letter from Hochschild to Ronald Prain, 17 October 1950.

${ }^{53}$ AHC Prain Papers. Box 1. File AMCO. Hochschild Correspondence, 19501951: Telegram from from Prain to Hochschild, 6 June 1950.

${ }^{54}$ AHC Prain Papers. Box 1. File AMCO. Hochschild Correspondence, 19501951, Letter from Prain to Hochschild, 20 October 1950.

${ }^{55}$ AHC Prain Papers. Box 1. File AMCO. Hochschild Correspondence, 19501951: Letter from Harold Hochschild to Ronald Prain, 5 January 1950; Letter from Prain to Hochschild, 11 June 1950.

${ }^{56}$ AHC Prain Papers. Box 1. File AMCO. Hochschild Correspondence, 19501951: Statement of Hochschild, - Submitted to The Committee on Ways and Means House of Representatives, Friday February 10, 1950.

${ }^{57}$ AHC Prain Papers. Box 1. File AMCO. Hochschild Correspondence, 19501951: Letter from Hochschild to Prain, 4 January 1951.

${ }^{58}$ AHC Prain Papers. Box 1. File AMCO. Hochschild Correspondence, 19501951: Letter from Prain to Hochschild, 31 January 1951.

${ }^{59}$ AHC Prain Papers. Box 1. File AMCO. Hochschild Correspondence, 19501951: Letter from Hochschild to Prain, 17 April 1951. 
${ }^{60}$ AHC Prain Papers. Box 1. File AMCO. Hochschild Correspondence, 19501951: Memorandum by Wm Bringhurst "Domicile - Rhodesian Companies", 25 April 1951.

${ }^{61}$ AHC Prain Papers. Box 1. File AMCO. Hochschild Correspondence, 19501951: Letter from Prain to Hochschild, 3 May 1951.

${ }^{62}$ AHC Prain Papers. Box 1. File AMCO. Hochschild Correspondence, 19501951: Memorandum by Wm Bringhurst "Domicile - Rhodesian Companies", 25 April 1951.

${ }^{63}$ AHC Prain Papers. Box 1. File AMCO. Hochschild Correspondence, 19501951: Ronald Prain to Harold Hochschild, 7 May 1951.

${ }^{64}$ Ibid.

65 Ibid.

${ }^{66}$ Ibid.

${ }^{67}$ AHC Prain Papers. Box 1. File AMCO. Hochschild Correspondence, 19501951: Telegram from Hochschild to Prain, 15 June 1951.

${ }^{68}$ AHC Prain Papers. Box 1. File AMCO. Hochschild Correspondence, 19501951: Prain, Notes on Domicile, 29 September 1951.

${ }^{69}$ Ibid.

${ }^{70}$ Ibid.

${ }^{71}$ Ibid.

${ }^{72}$ AHC Prain Papers. Box 1. File AMCO. Hochschild Correspondence, 19501951: Letter from Prain to Hochschild, 7 November 1951.

${ }^{73}$ AHC Prain Papers. Box 1. File AMCO. Hochschild Correspondence, 1952-54: Letter from Prain to Hochschild, 10 January 1952.

${ }^{74}$ NA T233/2161 - Section 468 of Income Tax Act (Migration of Companies): review of policy with special reference to Rhodesian Selection Trust, and Holland, Hannen and Cubitts (1952), 'Statement from Chairman 8 Jan 1952 with the Directors Report and Accounts for the year ending 30 June 1951.'

${ }^{75}$ NA T233/2161 - Section 468 of Income Tax Act (Migration of Companies): review of policy with special reference to Rhodesian Selection Trust, and Holland, Hannen and Cubitts (1952). CAB/129/45 'Closer Association in Central Africa: Memorandum by the Secretary of State for the Colonies and Secretary of State for Commonwealth Relations', 3 May 1951. was

${ }^{76}$ NA T233/2161 - Section 468 of Income Tax Act (Migration of Companies): review of policy with special reference to Rhodesian Selection Trust, and Holland, Hannen and Cubitts (1952).

${ }^{77}$ NA T233/2161 Advisory Panel Meeting, Rhodesian Selection Trust and Associated Companies (1952).

${ }^{78}$ Ibid.

${ }^{79}$ BGA ACC38/0209 Julian Crossley, Chairman of Barclays Bank (Dominions, Colonies and Overseas) Diary, 19 January 1951.

${ }^{80}$ For an explanation of excess profits tax policies under the Labor government see M. Daunton, Just Taxes: The Politics of Taxation in Britain, 1914-1979, (Cambridge, Cambridge University Press, 2002), pp. 200-203.

${ }^{81}$ NA T233/2161 Advisory Panel Meeting, Rhodesian Selection Trust and Associated Companies (1952).

${ }^{82}$ NA T233/2161 Memo 'Sir Bernard Gilbert', 30 July 1952; NA T233/2161 Memo to Mr Compton, 28 August 1952.

83 "Roan Antelope Copper Mines Ltd," The Times [London, England], 4 February 1952, 8. 
${ }^{84}$ AHC Prain Papers. Box 1. File AMCO.. Hochschild Correspondence, 195254: Prain to Hochschild 10 January 1952.

${ }^{85}$ AHC Prain Papers. Box 1. File AMCO. Hochschild Correspondence, 1952-54: Bringhurst to Hinves, 21 January 1952.

${ }^{86}$ NA T233/2162 'Note of Reasons for the Advisory Panel's Recommendation' by R.H. Binder, 23 October 1952.

${ }^{87}$ Ibid.

${ }^{88}$ Ibid.

${ }^{89}$ NA T233/2162 'Mr Drake: Item 3 and Item 4', 12 February 1953.

${ }^{90}$ NA T233/2161 Draft Memo on S. 468 Income Tax Act, 1952, n.d.

${ }^{91}$ NA T233/2161 Draft Memo on S. 468 Income Tax Act, 1952, n.d.; NA

T233/2161 U.S. Capital Investment in the Commonwealth, 28 August 1952.

${ }^{92}$ NA T233/2161 Letter to Mr Lees, 26 November 1952.

${ }^{93}$ NA T233/2161 Memo on S. 468 Income Tax Act, 1952.

${ }^{94}$ NA T233/2162 Confidential Memo, 23 January 1953.

${ }^{95}$ Ibid.

${ }^{96}$ NA T233/2162 Memo on S. 468 Income Tax Act, 1952.

${ }^{97}$ NA T233/2162 Memo on S. 468 Income Tax Act, 1952 - Appendix 3,

${ }^{98}$ NA T233/2162 Mr Compton, Migration of Companies, 4 December 1952.

${ }^{99}$ Ibid.

${ }^{100}$ NA T233/2162 Mr Leslie Rowan, Migration of Companies from the U.K., 17

December 1952.

${ }^{101}$ NA T233/2161 Advisory Panel Meeting, Rhodesian Selection Trust and Associated Companies (1952). Welensky became leader of the 'unofficials' within Northern Rhodesia's Legislative Council in 1945. He was a strong proponent for amalgamation and became the Federation's Minister for Transport at its creation and eventually Prime Minister in 1956.

102 Andrew Cohen, 'The politics and economics of decolonization in Africa: The failed experiment of the Central African Federation (London, I B Tauris 2017) p.40

${ }^{103}$ NA T233/2161 Roy Welensky to Ronald Prain, 5 May 1952.

${ }^{104}$ NA T233/2162 E. Melville, Colonial Office, to H.L. Jenkyns, Treasury, 29

January 1952.

${ }^{105}$ NA T233/2162 'Welensky', 29 Janaury, 1952; NA T233/2162 W. Armstrong, Treasury, to E. Melville, Colonial Office, 2 February 1953.

106 NA T233/2162 J.A.R Pimlott to St J. Trend, 5 December 1952; NA

T233/2162 St J. Trend to J.A.R, Pimlott, 11 December 1952.

${ }^{107}$ NA T233/2162 Oliver Lyttelton, Colonial Office to R.A. Butler, Treasury, 18

December 1952; NA T233/2162 R.A. Butler, Treasury to Oliver Lyttelton,

Colonial Office, 23 December 1952.

${ }^{108}$ NA T233/2162 'Note of reasons for the Advisory Panel's recommendation', 23 October, 1952; NA T233/2161 S.L. Lees (Treasury) to R.C Nicholas (Inland Revenue), 29 September 1952.

${ }^{109}$ NA T233/2162 The Migration of Companies (S. 468 of the Income Tax Act, 1952), 20 January 1953.

110 Ibid.

${ }^{111}$ NA T233/2162 The Migration of Companies (S. 468 of the Income Tax Act, 1952), 20 January 1953; NA T233/2162 'Draft Letter to R.L. Prain', n.d.

112 NA T233/2162 Memo, 19 January 1953. 
${ }^{113}$ NA T233/2162 Mr Trend, 'Income Tax Act, 1952. Section 468. Relations with the Colonial Office', 27 January 1953.

${ }^{114}$ NA T233/2162 John Boyd Carpenter, Treasury, to Oliver Lyttelton, Colonial Office, 3 March 1953; NA T233/2162 Letter to from Mr Compton to Lord Kennet, 6 March 1953; NA T233/2162 Letter from Lord Kennet to Mr Compton, 6 March 1953.

115 NA T233/2162 Oliver Lyttelton, Colonial Secretary, to RAB Butler, Chancellor of the Exchequer, 17 March 1953.

116 NA T233/2162 The Migration of Companies (S. 468 of the Income Tax Act, 1952), 20 January 1953; David R. Stanford, Overseas Trade Corporations

(London: Sweet and Maxwell, 1958); Sarah Stockwell, "Trade, Empire, and the Fiscal Context of Imperial Business during Decolonization," Economic History Review 57, no. 1 (2004): 142-60.

${ }^{117}$ See Michie, Ranald. The London Stock Exchange: A History. Oxford: Oxford University Press, 1999, especially pages 235-286; Mollan, Simon, and Ranald Michie. 2012. "The City of London as an International Commercial and Financial Center since 1900." Enterprise and Society 13 (3): 538-87. 


\section{References}

Belich, James. Replenishing the Earth: The Settler Revolution and the Rise of the Angloworld. Oxford University Press, 2011.

Boughey, David. "British Overseas Railways as Free-Standing Companies, 1900-1915." Business History 51, no. 3 (May 2009): 484-500.

Butler, L. J. "Business and British Decolonisation: Sir Ronald Prain, the Mining Industry and the Central African Federation." The Journal of Imperial and Commonwealth History 35, no. 3 (September 2007): 459-84.

L. J. Butler Copper Empire: Mining and the Colonial State in Northern Rhodesia, c.1930 - 1964. Basingstoke: Palgrave, 2007.

Cain, Peter J., and Anthony G. Hopkins. British Imperialism: 1688-2000. London: Pearson Education, 2002.

Casson, Mark. "An Economic Theory of the Free-Standing Company." In The Free Standing Company in the World Economy, 1830-1996, edited by Mira Wilkins and Harm Schröter, 99-128. Oxford: Oxford University Press, 1998.

Casson, Mark. "Institutional Diversity in Overseas Enterprise: Explaining the Free-Standing Company." Business History 36, no. 4 (1994): 95-108.

Chandler, Alfred. Scale and Scope: The Dynamics of Industrial Capitalism. Cambridge MA: Harvard University Press, 1990.

Chapman, Stanley. "British-Based Investment Groups Before 1914." The Economic History Review 38, no. 2 (1985): 230-47.

Cini, Michelle, and Nieves Pérez-Solórzano Borragán. European Union Politics. Oxford: Oxford University Press, 2013.

Cohen, Andrew, The politics and economics of decolonization in Africa: The failed experiment of the Central African Federation, London: I B Tauris 2017.

Collins, Julie H, and Douglas A Shackelford. "Corporate Domicile and Average Effective Tax Rates: The Cases of Canada, Japan, the United Kingdom, and the United States." International Tax and Public Finance 2, no. 1 (1995): $55-83$.

Corley, T. a. B. "Free-Standing Companies, Their Financing, and Internalisation Theory." Business History 36, no. 4 (October 1994): 109-17.

Daunton, Martin. Just Taxes: The Politics of Taxation in Britain, 1914-1979. Cambridge: Cambridge University Press, 2007.

Davis, Lance. "The Late Nineteenth-Century British Imperialist: Specification, Quantification and Controlled Conjectures." In Gentlemanly Capitalism and British Imperialism, edited by Raymond E. Dumett, 82-112. London: Longman, 1999.

Davis, Lance, and Robert Huttenback. Mammon and the Pursuit of Empire: The Political Economy of British Imperialism, 1860-1912. Cambridge: Cambridge University Press, 1986.

De Landa, Manuel. A Thousand Years of Nonlinear History. Zone Books New York, 1997.

Doyle, Michael W. Empires. Cornell University Press, 1986.

Edelstein, Michael. "Foreign Investment and Accumulation, 1860-1914." In The Economic History of Britain since 1700, Volume Two: 1860-1939, edited by R Floud and D McCloskey, 173-96. Cambridge, 1994.

Eden, Lorraine. "Taxes, Transfer Pricing and the Multinational Enterprise." In The Handbook of International Business, edited by Alan Rugman and 
Thomas Brewer, 591-619. Oxford, 2001.

Eden, Lorraine. Taxing Multinationals: Transfer Pricing and Corporate Income Taxation in North America. Toronto: University of Toronto Press, 1998.

Eden, Lorraine, Stefanie Lenway, and Douglas A Schuler. "From the Obsolescing Bargain to the Political Bargaining Model." In Academy of International Business Annual Meetings, Stockholm, Sweden, July, 2004.

Fieldhouse, David Kenneth. Black Africa 1945-1980: Economic Decolonization and Arrested Development. London: Routledge, 1986.

Fieldhouse, David Kenneth. The West and the Third World: Trade, Colonialism, Dependence, and Development. Oxford: Blackwell, 1999.

Gerriets, Marilyn. "The Rise and Fall of a Free-Standing Company in Nova Scotia: The General Mining Association." Business History 34, no. 3 (1992): 16-48.

Gray, Richard The two nations: Aspects of the development of race relations in the Rhodesias and Nyasaland. Oxford: Oxford University Press, 1960.

Greenhill, Robert G. "Investment Group, Free-Standing Company or Multinational? Brazilian Warrant, 1909-52.” Business History 37, no. 1 (January 1995): 86-111.

Greenhill, Robert G. "Investment Group, Free-Standing Company or Multinational? Brazilian Warrant, 1909-52.” Business History 37, no. 1 (1995): 86-111.

Havinden, Michael Ashley, and David George Meredith. Colonialism and Development: Britain and Its Tropical Colonies 1850-1960. London: Routledge, 1993.

Hellman, Joel S, Geraint Jones, and Daniel Kaufmann. "Seize the State, Seize the Day: State Capture and Influence in Transition Economies." Journal of Comparative Economics 31, no. 4 (2003): 751-73.

Hennart, Jean-Francois. "Transaction-Cost Theory and the Free-Standing Firm." In The Free Standing Company in the World Economy, 1830-1996, edited by Mira Wilkins and Harm Schröter, 65-98. Oxford: Oxford University Press, 1998.

Hobson, John Atkinson. Imperialism: A Study. London, 1902.

Houston, Tom, and John H. Dunning. UK Industry Abroad. London: Financial Times, 1976.

Jones, Charles. "'Business Imperialism'and Argentina, 1875-1900: A Theoretical Note." Journal of Latin American Studies 12, no. 2 (1980): 437-44.

Jones, Charles. "Commercial Banks and Mortgage Companies." In Business Imperialism, 1840-1930: An Enquiry Based on British Experience in Latin America, edited by D.C.M. Platt, 17-52. Oxford: Clarendon Press, 1977.

Jones, Charles. "Institutional Forms of British Foreign Direct Investment in South America." Business History 39, no. 2 (April 1997): 21-41.

Jones, Geoffrey. "British Overseas Banks as Free-Standing Companies, 18301996." In The Free Standing Company in the World Economy, 1830-1996, edited by Mira Wilkins and Harm Schröter, 344-60. Oxford: Oxford University Press, 1998.

Jones, Stuart. "Origins, Growth and Concentration of Bank Capital in South Africa, 1860-92." Business History 36, no. 3 (July 1994): 62-80.

Kenwood, George, and Alan Lougheed. Growth of the International Economy 1820-2000: An Introductory Text. London: Routledge, 1999.

Klein, Naomi. No Logo: Taking on the Brand Bullies. New York: Picador, 1999. 
Krasner, Stephen D. "Rethinking the Sovereign State Model." Review of International Studies 27 (2001): 17-42.

Kubicek, Robert V. Economic Imperialism in Theory and Practice: The Case of South African Gold Mining Finance 1886-1914. Durham, NC: Duke University Press, 1979.

Lenin, Vladimir Il'ich. Imperialism: The Highest Stage of Capitalism. Resistance Books, 1999.

Michie, Ranald. The City of London: Continuity and Change since 1850. London: Macmillan, 1991.

Miller, Rory. "British Free-Standing Companies on the West Coast of South America." In The Free Standing Company in the World Economy, 18301996, edited by Mira Wilkins and Harm Schröter, 218-51. Oxford: Oxford University Press, 1998.

Miller, Rory. "Informal Empire in Latin America." Winks, Robin W., The Oxford History of the British Empire 5 (1999).

Mollan, Simon. "Business Failure, Capital Investment and Information: Mining Companies in the Anglo-Egyptian Sudan, 1900-13." The Journal of Imperial and Commonwealth History 37, no. 2 (2009): 229-48.

Mollan, Simon. 2010. "S. Hoffnung and Co: The Case of a Market Intermediary in Australia, 1851-1980." Consumption, Markets and Culture 13 (1): 7-30.

Mollan, Simon. "The Free-Standing Company: A 'zombie' Theory of International Business History?" Journal of Management History 22, no. 2 (2018): 156-73.

Mollan, Simon, and David K. Kelsey. "An Overview of the Business History of the International Mining Industry." In Contemporary Issues in Mining, edited by Nigel Finch. Sydney: Palgrave Macmillan, 2012.

Mollan, Simon, and Ranald Michie. "The City of London as an International Commercial and Financial Center since 1900." Enterprise and Society 13, no. 3 (January 27, 2012): 538-87.

Mollan, Simon, and Kevin Tennent. "International Taxation and Corporate Strategy: Evidence from British Overseas Business, circa 1900-1965.” Business History 57, no. 7 (2015): 1-28.

Moraña, Mabel, Enrique D Dussel, and Carlos A Jáuregui. Coloniality at Large: Latin America and the Postcolonial Debate. Duke University Press, 2008.

Motyl, Alexander J. Imperial Ends: The Decay, Collapse, and Revival of Empires. New York: Columbia University Press, 2013.

Newton, Scott. The Global Economy, 1944-2000: The Limits of Ideology. Arnold London, 2004.

Paris, Roland. "The Globalization of Taxation? Electronic Commerce and the Transformation of the State." International Studies Quarterly 47, no. 2 (2003): 153-82.

Piccotto, Sol. "Slicing a Shadow: Business Taxation in an International Framework." In Capitalism, Culture and Economic Regulation, edited by L. Hancher and M. Moran, 11-47. Oxford: Clarendon Press, 1989.

Platt, D.C.M. Business Imperialism, 1840-1930: An Inquiry Based on British Experience in Latin America. Oxford: Clarendon Press, 1977.

Pollard, Sidney. "Capital Exports, 1870-1914 Harmful or Beneficial?*." The Economic History Review 38, no. 4 (1985): 489-514.

Profeta, P., and S. Scabrosetti. The Political Economy of Taxation: Lessons from Developing Countries. Cheltenham: Edward Elgar, 2010. 
Razin, Assaf, and Joel Slemrod. "Introduction." In Taxation in the Global Economy, edited by Assaf Razin and Joel Slemrod, 1-11. Chicago: University of Chicago Press, 1990.

Schenk, Catherine. Britain and the Sterling Area - From devaluation to convertibility in the 1950's. London: Routledge, 1994.

Shah, Anwar, and Joel Slemrod. "Do Taxes Matter for Foreign Direct Investment?" The World Bank Economic Review 5, no. 3 (1991): 473-91.

Stanciu, Laura. "Free-Standing Companies in the Oil Sector in Romania and Poland Before 1948: Typologies and Competencies." Business History 42, no. 4 (October 2000): 27-66.

Stanford, David R. Overseas Trade Corporations. London: Sweet and Maxwell, 1958.

Steele, Murray. "Labour and the Central African Federation: Paternalism, Partnership and Black Nationalism, $1951-60$ " in The British Labour Movement and Imperialism (with Foreword by Tony Benn) edited by Billy Frank, Craig Horner and David Stewart. Newcastle upon Tyne: Cambridge Scholars, 2010

Somerville, J. J. B. "The Central African Federation," International Affairs Vol. 39, No. 3 (1963)

Stockwell, Sarah. "Trade, Empire, and the Fiscal Context of Imperial Business during Decolonization." Economic History Review 57, no. 1 (2004): 14260.

Tennent, Kevin. "Management and the Free-Standing Company: The New Zealand and Australia Land Company c . 1866-1900." The Journal of Imperial and Commonwealth History 41, no. 1 (March 2013): 81-97.

Tennent, Kevin. "Owned, Monitored, but Not Always Controlled: Understanding the Success and Failure of Scottish Free-Standing Companies, 1862-1910." The London School of Economics and Political Science (LSE), 2009.

Tignor, Robert L. Capitalism and Nationalism at the End of Empire: State and Business in Decolonizing Egypt, Nigeria, and Kenya, 1945-1963. Princeton, NJ: Princeton University Press, 1998.

Tomlinson, Jim. Managing the Economy, Managing the People: Narratives of Economic Life in Britain from Beveridge to Brexit. Oxford: Oxford University Press, 2017.

White, Nicholas J. British Business in Post-Colonial Malaysia, 1957-70: "NeoColonialism" or "Disengagement"? Abingdon: Routledge Curzon, 2004.

Wilkins, Mira. "The Free-Standing Company, 1870-1914: An Important Type of British Foreign Direct Investment." The Economic History Review, New Series, 41, no. 2 (1988): 259-82.

Wilkins, Mira. "The Free-Standing Company Revisited." In The Free Standing Company in the World Economy, 1830-1996, edited by Mira Wilkins and Harm Schröter, 3-66. Oxford: Oxford University Press, 1998.

Wilkins, Mira, and Frank Ernest Hill. American Business Abroad: Ford on Six Continents. Detroit: Wayne State University Press, 1964.

Wilkins, Mira, and Harm Schröter. The Free-Standing Company in the World Economy, 1830-1996. Edited by Mira Wilkins and Harm Schröter. Oxford Uni. Oxford, 1998.

Yacob, Shakila, and Nicholas J. White. 2010. "The 'unfinished Business' of Malaysia's Decolonisation: The Origins of the Guthrie 'Dawn Raid.'” Modern Asian Studies 44 (5): 919-60. 